\title{
Assessment of Volume Status with Cardiovascular Risk Factors in Hemodialysis Patients
}

\section{Hemodiyaliz hastalarında kardiyovaskuler riskin belirlenmesinde volüm durumunun rolü}

\author{
$\underline{\text { Bahar Gürlek Demirci }}{ }^{1}$, Emre Tutal $^{2}$, Orhan Guliyev ${ }^{2}$, Turan Çolak ${ }^{2}$, Fatma Nurhan Ozdemir Acar ${ }^{2}$, Siren Sezer $^{2}$ \\ ${ }^{1}$ Atatürk Eğitim ve Araştırma Hastanesi, Nefroloji Bilim Dalı, Ankara \\ ${ }^{2}$ Başkent Üniversitesi Tıp Fakültesi, Nefroloji Bilim Dalı, Ankara
}

Dergiye Ulaşma Tarihi: 18/04/2018 Dergiye Kabul Tarihi:30/04/2018 Doi: 10.5505/aot.2018.89410

\begin{abstract}
ÖZET
GíRiş ve AMAÇ: Kronik sıvı yükü hemodiyalize giren hastalarda sık karşılaşılan bir sorundur. Bu çalışmada, hemodiyalize giren hastalarda biyoimpedans analizi (BİA) ile ölçülen sıvı yükü parametreleri ile sistolik, diyastolik kan basıncı, nabız dalga hızı (PWv) nabız basıncı, kardiyak indeks (CI) ve kardiyak output (CO) gibi hemodinamik parametreler arasındaki ilişkinin gösterilmesi amaçlandı.

YÖNTEM ve GEREÇLER: Son dönem böbrek hastalığı tanısı ile en az üç aydır hemodiyalize giren ve medikal olarak stabil 100 hasta çalışmaya alındı. Biyoimpedans cihazı (BCM, Fresenius) ile yapılan vücut kompozisyon analizinde sistolik ve diyastolik kan basıncı, vücut kitle indeksi (VKI), yağsız doku indeksi (LTI), ekstraselüler sıvı volumü (ECW), intraselüler sıvı volumü (ICW), yağsız doku kütlesi (LTM) düzeyleri belirlendi. PWv, nabız basıncı (PP), CI, CO, sistolik basınç artışı (AIx) ve total vasküler direnç (TVR) nabız dalga hızı cihazı ile ölçüldü (Mobil-O-Graph).

BULGULAR: Ortalama yaş $47.5 \pm 16.2$ idi. Ultrafiltrasyon volumü ve hipervolemi sıklı̆g sistolik kan basıncı, ECW, ICW, VKİ, $(p<0.005)$; PWv, CO, TVR, CI ve AIx ile pozitif korele $(p<0.001)$, LTI ile ters orant1l saptandı $(\mathrm{p}<0.05)$. Hipervolemi, prediyaliz serum sodyum düzeyinden bağımsızdı. PP, CO, TVR, CI, AIx, $\mathrm{Kt} / \mathrm{V}$, E/I ve faz50 açısı PWV'nin belirleyicileri olarak saptandı $(\mathrm{p}<0.005)$. Sistolik kan basıncı, PP, CO, TVR, AIx, PWv, ECW, ICW ve E/I hipervoleminin belirleyicileri olarak saptandi $(\mathrm{p}<0.001)$.
\end{abstract}

TARTIŞMA ve SONUÇ: Çalışmamızda hipervoleminin nabız dalga hızı progresyonu, artmış sistolik kan basıncı, nabız basıncı ve vasküler direnç ile ilişkili olduğu gösterilmiş̧tir.

Anahtar Kelimeler: Hemodiyaliz, hipervolemi, biyoimpedans, arteryel sertlik

\begin{abstract}
INTRODUCTION: Chronic fluid overload is a common issue in patients undergoing hemodialysis. In present study, we aimed to investigate fluid volume parameters by bioimpedance analysis (BIA) and their relationship to hemodynamic parameters as systolic and diastolic blood pressure, pulse wave velocity (PWv), PP, cardiac index $(\mathrm{CI})$ and cardiac output $(\mathrm{CO})$ in patients ongoing hemodialysis.

METHODS: One hundred end stage renal disease patients who were medically stable and undergoing dialysis treatment for at least 3 months were enrolled to the study. Body compositions were analyzed with the BIA technique (BCM, Fresenius) that estimates systolic and diastolic blood pressure, body mass index (BMI) lean tissue index (LTI), extracellular volume (ECW), intracellular volume (ICW), lean tissue mass (LTM) and phase angle levels. PWv, pulse pressure, $\mathrm{CI}, \mathrm{CO}$, systolic pressure augmentation (AIx) and total vascular resistance (TVR) were evaluated with PWv analysis monitor (Mobil-O-Graph).

RESULTS: The mean age was $47.5 \pm 16.2$. Ultrafiltration volume and overhydration frequency were positively correlated with systolic blood pressure, ECW, ICW, BMI ( $<<0.05)$ and hemodynamic parameters as PWv, PP, CO, TVR, CI and AIx ( $\mathrm{p}<0.001$ ), and negatively correlated with LTI (p <0.05). PP, CO, TVR, CI, AIx, Kt/V, E/I and phi50 were the predictors of pulse wave velocity $(\mathrm{p}<0.05)$. Systolic blood pressure, PP, CO, TVR, CI, AIx, PWv, ECW, ICW and E/I were the predictors of overhydration ( $\mathrm{p}<0.001)$.
\end{abstract}

DISCUSSION and CONCLUSION: Present study concluded that overhydration is associated with increased PWv, systolic blood pressure, PP and vascular resistance

Keywords: Hemodialysis, hypervolemia, biyoimpedance, arterial stiffness 


\section{INTRODUCTION}

Cardiovascular disorders and hypertension are the leading causes of mortality in maintenance hemodialysis (MHD) patients (1). Hypervolemia is an independent risk factor for hypertension among end-stage renal disease (ESRD) patients (2). Thus adequate fluid management is one of the most important therapeutic goals of dialysis because volume overload in patients on MHD leads to increased cardiovascular morbidity and mortality (3) It is associated with left ventricular hypertrophy (2) protein energy wasting (PEW) (4) and inflammation (5). Protein-energy wasting, a condition of loss of muscle and visceral protein stores is a common complication and an important predictive factor for morbidity and mortality in ESRD patients. Incidence of PEW in MHD patients varies from $23 \%$ to $76 \%$ in different studies (6). Undernutrition, hormonal derangements, the dialysis procedure, uremic toxicity, oxidative stress and systemic inflammation may lead to MHD-related malnutrition (7). Several approaches based on clinical evaluation as history of weight loss, biochemical markers such as serum albumin, creatinine, lipid levels, body mass index (BMI) assessment and anthropometric measurements have been used to assess the PEW (8). BIA is a useful, simple, noninvasive technique for assessing body composition and its changes over time both in normal and CKD population (9)

Arterial stiffening is a progressive aging process that is accelerated by hypertension, metabolic syndrome, diabetes, atherosclerosis and renal disease (10). Pulse wave velocity (PWV) is a non-invasive measure of arterial stiffness and has a strong correlation with cardiovascular events and allcause mortality (11). In present study, we aimed to investigate fluid volume parameters by bioimpedance analysis (BIA) and their relationship to hemodynamic parameters as systolic and diastolic blood pressure, PWv, pulse pressure, cardiac index (CI) and cardiac output (CO).

\section{MATERIALS and METHODS}

Among 294 MHD patients, 100patients who were medically stable and undergoing dialysis treatment for at least 3 months were enrolled to the study. Exclusion criteria were as follows: acute infection, chronic inflammatory disease of unknown origin, recent surgery within 3 months or during follow-up, hospitalization, major cardiovascular events during follow-up, malignancy history and chronic liver disease.

\section{Clinical and biochemical assessments}

Serum concentrations of hemoglobin $(\mathrm{Hb})$; creatinine; calcium $(\mathrm{Ca})$, phousphorus $(\mathrm{P})$, intact parathyroid hormone (PTH); alkaline phosphatase (ALP), total, low-density lipoprotein (LDL), and high-density lipoprotein (HDL) cholesterol; triglyceride (TG); serum albumin; $\mathrm{C}$ reactive protein (CRP) were determined from retrospective clinical records.

\section{Anthropometric Measurements}

After measurement of body weight and height; bioimpedance spectroscopy analysis (BIA) was measured with the Body Composition Monitor (BCM) from Fresenius Medical Care, Deutschland GmbH. Four electrodes were placed on the right hand and foot on the side contralateral to the arteriovenous fistula (if present), of supine patients. Two electrodes were dorsally placed on the hand in the metacarpophalangeal articulations and in the corpus, respectively, $5 \mathrm{~cm}$ apart.The pair on the foot was located in the metatarsophalangeal and in the articulation, $6 \mathrm{~cm}$ apart. Dry weight (DW), fat mass (FM), fat free mass (FFM), body mass index (BMI) and muscle mass (MM) were analyzed.

\section{Pulse wave velocity (PWv) assessment}

Pulse wave velocity is defined as the velocity of the arterial pulse for moving along the vessel wall. Pulse wave velocity along the aorta was measured by using two ultrasound or pressure sensitive transducers fixed transcutaneously over the course of a pair of arteries separated by a known distance: the femoral and right common carotid arteries. PWV was calculated from measurements of pulse transit time and the distance, according to the following formula: PWV $(\mathrm{m} / \mathrm{s})=$ distance $(\mathrm{m}) /$ transit time ( $\mathrm{s})$. Measurement of PWV values was conducted after abstinence from caffeine or smoking and after an overnight fast without intake of antihypertensive drugs. PWV was determined by using the SphygmoCor CvMs V9 system and values $>7 \mathrm{~m} / \mathrm{s}$ was 
defined as increased. By this method we also calculate pulse pressure (PP), cardiac index (CI), cardiac output (CO), augmentation index (AI) and total vacular resistance (TVR). We achieved the data from retrospective records since we annually measure all patients post-dialysis PWv on the first day of year.

\section{Statistical Analysis}

Statistical analyses were performed by using SPSS software (Statistical Package for the Social Sciences, version 11.0, SSPS Inc, Chicago, IL, USA). Normality of data was analyzed by using a Kolmogorov-Smirnov test. All numerical variables with normal distribution were expressed as the means \pm standard deviations (SD), while variables with skew distribution were expressed as medians and interquartile range (IR). Categorical variables were expressed as percentages and compared by chi-square test. Normally distributed numeric variables were analyzed by independent samples $t$ or One-Way ANOVA (Post-Hoc Tukey) tests. Skew distributed numeric variables were compared using the Mann-Whitney U and Kruskal Wallis tests. SpearmanR and Pearson Correlation tests were used for correlation analyses. A p-value $<0.05$ was considered as statistically significant.

\section{RESULTS}

The mean age of study population was $47.5 \pm$ 16.2 years. Demographic characteristics of patients were given in Table 1 . Patients with volume overload were found to use significantly more antihypertensive medications (p:0.02). Forty two of patients were overhydrated at the time of study.

The mean values of ECW, ICW, BMI, LTI, LTM, PWv, PP, CO, TVR, CI, AI and phi50 were given in Table 2. The mean systolic blood pressure was $114 \pm 20 \mathrm{mmHg}$, the mean diastolic blood pressure was $90.5 \pm$ $25.6 \mathrm{mmHg}$. The median ultrafiltration volume was $2998.7 \pm 1120.9 \mathrm{ml}$ and overhydration frequency $(\mathrm{OH} \%)$ were $0.4 \pm 1.9$. In correlation analysis, ultrafiltration volume and overhydration frequency were positively correlated with systolic blood pressure, ECW, ICW, BMI $(p<0.05)$ and hemodynamic parameters as PWv, PP, CO, TVR, CI and AIx
( $\mathrm{p}<0.001)$; and negatively correlated with LTI $(p<0.05)$. In linear regression analysis PP, CO, TVR, CI, AIx, Kt/V, E/I and phi50 were the predictors of pulse wave velocity $(\mathrm{p}<0.05)$. Moreover; systolic blood pressure, PP, CO, TVR, CI, AIx, PWv, ECW, ICW and E/I were the predictors of overhydration $(\mathrm{p}<0.001)$.

Table 1. Demographic characteristics of study population

\begin{tabular}{|l|l|}
\hline Age (mean \pm SD, years) & $47.5 \pm 16.2$ \\
\hline Gender & $73(56 \%)$ \\
Male (n) (\%) & $57(44 \%)$ \\
Female (n) (\%) & $9.1 \pm 5.4$ \\
\hline $\begin{array}{l}\text { Duraton of dialysis } \\
\text { (mean } \pm \text { SD, years) }\end{array}$ & \\
\hline $\begin{array}{l}\text { CKD etiology (n) (\%) } \\
\text { Diabetes Mellitus }\end{array}$ & $32(24 \%)$ \\
Hypertension & $19(14 \%)$ \\
Glomerulonephritis & $17(13 \%)$ \\
PKD & $7(5 \%)$ \\
Others & $55(44 \%)$ \\
\hline Body weight (kg) & $68.8 \pm 15.4$ \\
\hline BMI (kg/m $\left.{ }^{2}\right)$ & $25.4 \pm 4.3$ \\
\hline $\begin{array}{l}\text { Abbrevations;CKD; chronic kidney disease, } \\
\text { PKD; policyctic kidney disease, BMI; body } \\
\text { mass index }\end{array}$ \\
\hline
\end{tabular}

\section{DISCUSSION}

Present study demonstrate an association between overhydration with arterial stiffness and other hemodynamic parameters as systolic and diastolic blood pressure, pulse wave velocity, pulse pressure, cardiac index and cardiac output.

Hypervolemia is one of the most important factor that results in higher levels of blood pressure in patients with chronic kidney disease. Present study showed that overhydrated patients have increased both systolic and diastolic blood pressures. Paglialonga et al. detected significant correlation between overhydration and diastolic blood pressue as similar to our study (14). Another trial that supports our study was on pediatric hemodialysis patients. They showed that fluid accumulates during the interdialytic period and contributes to increased blood pressure (15). 
Table 2. The mean values of bioimpedance analysis

\begin{tabular}{|c|c|}
\hline $\mathrm{ECW}(\mathrm{L})$ & $14.4 \pm 3.0$ \\
\hline ICW (L) & $18.2 \pm 4.4$ \\
\hline BMI (kg/m2) & $24.3 \pm 4.6$ \\
\hline LTI (kg/m2) & $13.3 \pm 3.1$ \\
\hline LTM (kg) & $60.4 \pm 36.7$ \\
\hline $\mathrm{PWv}(\mathrm{m} / \mathrm{sec})$ & $8.1 \pm 2.1$ \\
\hline $\mathrm{PP}(\mathrm{mmHg})$ & $45.3 \pm 15.0$ \\
\hline $\mathrm{CO}(\mathrm{L} / \mathrm{min})$ & $4.9 \pm 1.2$ \\
\hline TVR (dyn s cm $\left.\mathrm{cm}^{-5} \mathrm{~m}^{-2}\right)$ & $1.9 \pm 1.1$ \\
\hline $\mathrm{CI}(\mathrm{L} / \mathrm{min} / \mathrm{m} 2)$ & $2.8 \pm 0.7$ \\
\hline $\operatorname{AIx}(\%)$ & $21.4 \pm 12.8$ \\
\hline Phi50 ( $\left(^{\circ}\right)$ & $4.4 \pm 1.0$ \\
\hline SBP (mmHg) & $114 \pm 20$ \\
\hline $\mathrm{DBP}(\mathrm{mmHg})$ & $90.5 \pm 25.6$ \\
\hline $\mathrm{E} / \mathrm{I}$ ratio & $0.8 \pm 0.1$ \\
\hline \multicolumn{2}{|c|}{$\begin{array}{l}\text { Abbreviations: ECW (extracellular water), } \\
\text { ICW (Intracellular water), BMI (body mass } \\
\text { index), LTI (lean tissue index), LTM (lean } \\
\text { tissue mass), PWv (pulse wave velocity), PP } \\
\text { (pulse pressure), CO (cardiac output), TVR } \\
\text { (total vascular resistance), CI (cardiac index), } \\
\text { AIx (augmentation index), SBP (systolic blood } \\
\text { pressure), DBP (diastolic blood pressure) }\end{array}$} \\
\hline
\end{tabular}

Overhydration, has also been linked with arterial stiffness (12) and left ventricular dysfunction (13) and is strongly associated with poor cardiovascular outcomes Consistent with the literature, our study revealed that ultrafiltration volume and overhydration frequency were positively correlated with PWv and AI. As similar, Safar ME showed that interdialytic weight gain and hypervolemia are associated with increased aortic PWV (16). In addition, Bia et al. was able to show that PWV correlated to both $\mathrm{OH}$ and $\mathrm{OH} / \mathrm{ECW}$ in a hemodialysis cohort (17). However, a previous study could not find any association between overhydration and PWV (18). They explained this conflicting data with the fluctuating levels of PWv in hemodialysis cycle.

Another important finding of our study was the positive correlation between overhydration and AIx. It is well known that the elevated AIx is a major determinant of the cardiac afterload and therefore for the development of left ventricular hypertrophy $(19,20)$. To our knowledge, the leading cause of the increase in AIx is increase in PWv. A previous trial demonstrated that AIx is elevated in hemodialysis patients and significant reductions observed in AIx after simultaneous volume correction. In contrast to our study, PWv did not decrease significantly by volume withdrawal and they explained this data due to a the small number of study population.

The lean tissue index is an important measurement related to the amount of skeletal muscle and reflects patients nutritional status. Present study we detected a negative correlation between overhydration and LTI. The LTI and its relationship with mortality have been widely studied in haemodialysis patients. Recent studies, in conjunction with our findings, would support a relation between overhydration and malnutrition in patients ongoing hemodialysis (21).

Limitations of this study include first the retrospective nature of the data collection. Second, given the small sample size, our results should be interpreted with caution. Third, we didn't examine the lifestyle as exercise that could affect bioimpedance analysis and cardiovascular outcomes.

In conclusion, by this trial we showed that overhydration is associated with increased PWv, systolic blood pressure, pulse pressure and vascular resistance. Thus we recommend regular monitoring arterial pressure waves and body fluid measurements to protect patients undergoing hemodialysis from the complications related to fluid overload.

\section{Conflict of Interest: None}

\section{REFERENCES}

1) Zareba $W$. Initiation of dialysis: Trigger or cause of cardiovascular events? Kidney Int. 2015; 88: 942-94

2) Juan-García I, Puchades MJ, Sanjuán $R$ et al. Echocardiographic impact of hydration status in dialysis patients. Nefrologia. 2012; 32: 94-102.

3) Wizemann V, Wabel $P$, Chamney $P$ et al. The mortality risk of overhydration in haemodialysis patients. Nephrol Dial Transplant. 2009; 24: 1574-9 
4) Edefonti A, Mastrangelo A, Paglialonga F. Assessment and monitoring of nutrition status in pediatric peritoneal dialysis patients. Perit Dial Int. 2009;29 Suppl 2:S176-9.

5) Canpolat N, Caliskan S, Sever L et al. Malnutrition and its association with inflammation and vascular disease in children on maintenance dialysis. Pediatr Nephrol. 2013; 28: 2149-56.

6) Heimburger O, Qureshi AR, Blaner WS. Hand-grip muscle strength, lean body mass and plasma proteins as marker of nutritional status in patients with chronic renal failure close to start to dialysis therapy. Am J Kidney Disease. 2000; 6; 1213-1225.

7) Fouque D, Kalantar-Zadeh K, Kopple J et. al. A proposed nomenclature and diagnostic criteria for protein-energy wasting in acute and chronic kidney disease. Kidney Int. 2008; 73: 391-8.

8) Clinical practice guidelines for nutrition in chronic renal failure. K/DOQI, National Kidney Foundation. Am J Kidney Diseases. 2000; 35: 1-140

9) De Lorenzo A, Andreoli A, Matthie $J$ et al. Predictingbody cell mass with bioimpedance by using theoretical methods: a technological review. J Appl Physiol. 1997; 85: 1542-58.

10) Streese L, Deiseroth A, Schäfer J, SchmidtTrucksäss A, Hanssen H. Exercise, Arterial Crosstalk-Modulation, and Inflammation in an Aging Population: The ExAMIN AGE Study. Front Physiol. 2018; 9: 116.

11) Alejandro $D$, Yanina $Z$, Daniel $B$, Franco $S$, Victoria $\mathrm{R}$, Edmundo CF. Reference intervals of aortic pulse wave velocity assessed with an oscillometric device in healthy children and adolescents from Argentina. Clin Exp Hypertens. 2018; 9: 1-12.

12) Akdam $H$, Oğunc $H$, Alp A et al. Assessment of volume status and arterial stiffness in chronic kidney disease. Ren Fail. 2014; 36(1): 28-34

13) Lin Y-P, Chen C-H, Yu W-C, Hsu T-L, Ding PY-A, Yang W-C. Left ventricular mass and hemodynamic overload in normotensive hemodialysis patients. Kidney Int. 2002; 62(5): 1828-1838.
14) Paglialonga F, Consolo $S$, Galli M.A, Testa $S$, Edefonti A. "Interdialytic weight gain in oligoanuric children and adolescents on chronic hemodialysis. Pediatric Nephrology. 2015; 30: 999-1005

15) Burenand PN, Inrig JK, "Hypertension and hemodialysis: pathophysiology and outcomes in adult and pediatric populations. PediatricNephrology. 2012; 27: 339-350

16) Safar ME, Asmar R, Benetos A, Levy BI, London GM: Sodium, large arteries, and diuretic compounds in hypertension. Am J Med Sci. 1994; 307[Suppl 1]: 3-8

17) Bia D, Galli C, Valtuille R et al. Hydration Status Is Associated with Aortic Stiffness, but Not with Peripheral Arterial Stiffness, in Chronically Hemodialysed Patients. Int J Nephrol. 2015. https://doi.org/10.1155/2015/628654 PMID: 26167301

18) Mitsides N,Cornelis $T$, Broers $\mathrm{NJH}$ et al. Extracellular overhydration linked with endothelial dysfunction in the context of inflammation in haemodialysis dependent chronic kidney disease. PLoS One. 2017;12(8): e0183281. doi: 10.1371/journal.pone.0183281

19) London GM, Marchais SJ, Guerin AP, Metivier F, Pannier B: Cardiac hypertrophy and arterial alterations in end-stage renal disease: Hemodynamic factors. Kidney Int. 1993;43: 42-49

20) Covic A, Goldsmith DJA, Panaghiu L, Covic M, Sedor J: Analysis of the effect of hemodialysis on peripheral and central arterial pressure waveforms. Kidney Int. 2000;57:2634-2643

21) Rosenberger $J$, Kissova $V$, Majernikova $M$ et al. Body composition monitor assessing malnutrition in the hemodialysis population independently predicts mortality. JRenNutr. 2014;24: 172-176 